\title{
頭頸部腫瘍に対するレーザー外科の経験
}

\author{
江口 実美・吉江 信夫・大橋徹・仲田 充雄
}

\section{Laser Surgery for the Head and Neck Tumors}

\author{
Sanetomi Eguchi, Nobuo Yoshie, Toru Ohashi, Mistuo Nakata \\ (The University of Tsukuba)
}

20 cases (14 patients) of head and neck tumors were treated by $\mathrm{Co}_{2}$ laser surgery in ENT clinic, the University of Tsukuba, during the period from Nov. 1, 1979 to Aug. 15,1980 .

It was thought that laser surgery is a powerful treatment for benign tumors and local recurrence of malignant primary tumors.

It was speculated that laser surgery will be desirable treatment for malignant melanoma and small, superficial primary cancer.

It was concluded that $50 \mathrm{~W} \sim 60 \mathrm{~W}$, defocused beam vaporization $(1 \mathrm{~mm} \sim 2 \mathrm{~mm})$ for benign tumors, and $1 \mathrm{~mm} \sim 0.5 \mathrm{~mm}$ beam vaporization for malignant tumors are recommendable laser conditions for the head and neck tumors.

\section{は じめに}

炭酸ガスレーザーが1965年 C. K. N. Patel ${ }^{11}$ によって開発されて以来, レーザーのメスとしての 医学的応用がなされるようになっている。本邦においては，1969年澺沢2) らによって開発が始めら れ，ようやく，外科領域での臨床応用が試みられつつある。耳鼻咽喉科 (頭頸部) 領域での炭酸ガ スレーザー手術の臨床応用の歴史は浅く，10年に満たない(3)ー8).

著者らは, 炭酸ガスレーザーの持つ特徵, すなわち, 出血が少ない。熱作用による殺菌効果, 限 局的組織侵襲, 腫瘍細胞の転移防止効果, 術後疼痛が少ない。速い創傷治癒, などを生かしたレー ザー外科の有効性を各種頭頸部領域疾患に対して試みているので, てれまでに経験した臨床実績之 その経験から考えられる問題点について報告する.

\section{対 象 症 例}

昭和54年11月 1 日から昭和55年 8 月15日まで の期間に筑波大学耳鼻咽喉科においてレーザー 手術を行った件数は20件, 症例としては14例で ある。そのうちわけは表 1 に示すごとく，良性 腫瘍 4 例（舌リンパ管腫, 舌乳頭腫, 舌白斑症 喉頭乳頭腫の各 1 例）之覀性腫瘍10例（上顎扁
平上皮癌局所再発 3 例, 口蓋扁平上皮癌 1 例, 舌根部悪性黑色腫 1 例, 翼突部軟骨肉腫 1 例, 上咽頭扁平上皮癌局所再発 2 例，煩粘膜扁平上 皮癌局所再発 1 例, 下咽頭扁平上皮癌再発 1 例）である。 
表। 筑波大学耳鼻咽喉科レーザー症例（昭和54年11月 1 日〜 55 年 8 月15日）

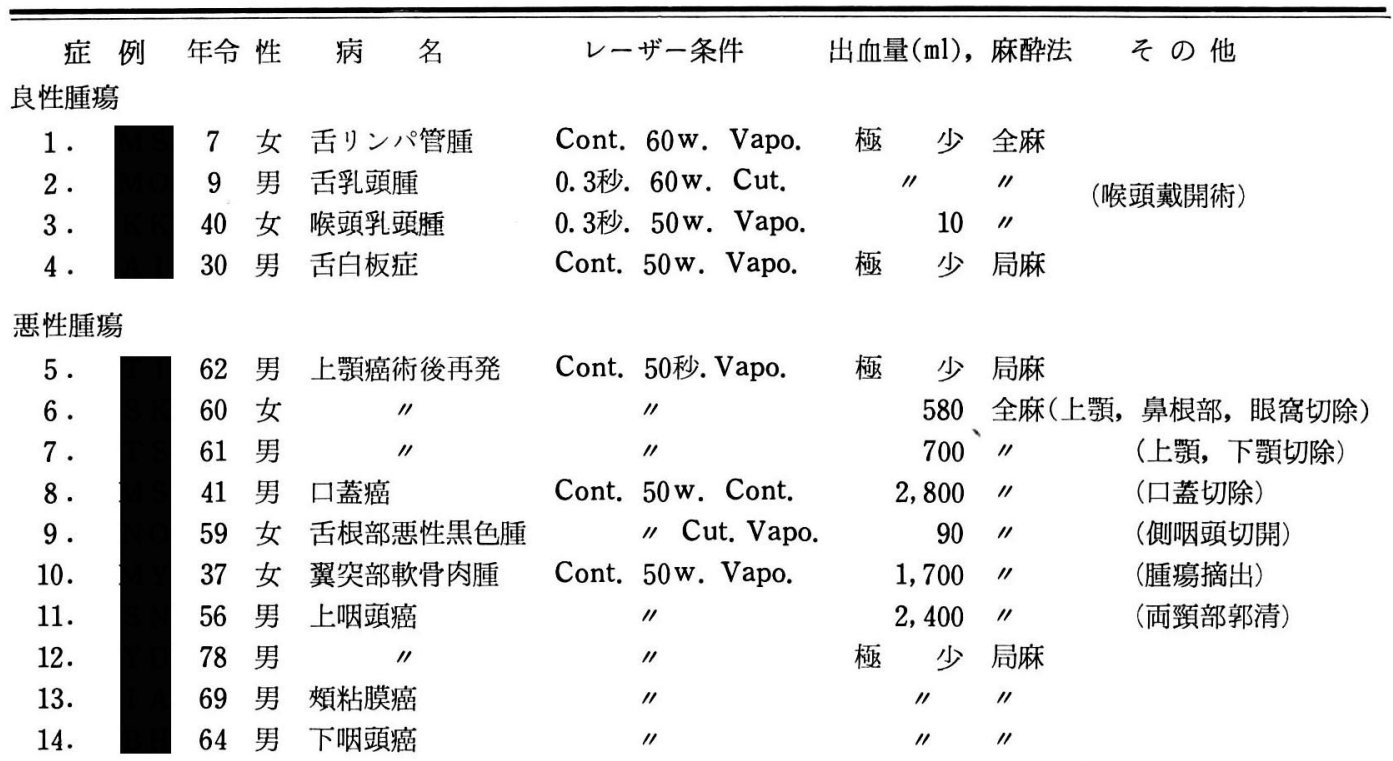

(注) Cont : Continuous

Vapo : Vaporiz ation Cut : Cutting

\section{使 用 装 置}

今回使用した炭酸ガスレーザー手術装置は持 田製薬が開発した Medilaser-S, Model MEL442 である. 本装置は $0 \mathrm{~W} \sim 60 \mathrm{~W}$ の連続可変出 力を持ち, 二関節マニピレーターを有し, 光軸 ずれがなく、レーザー出力減衰が少ない、レー

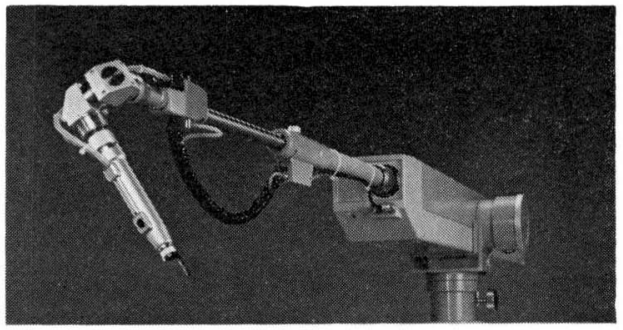

図Ｉ．持田製薬開発炭酸ガスレーザー装置. 右に全体像，左にマニピレーター部の拡大を示す．

\section{治療法と経過・成績}

レーザー条件：舌乳頭腫例之喉頭乳頭腫例計 2 例について, 0.3 秒パルス照射を行った以外 を用い, Cutting (組織切開) を行ったもの 2 はすべて持続照射を行った. 出力は $50 \mathrm{~W} \sim 60 \mathrm{~W}$
ザーは，連続動作と0. 02〜 9. 99秒間で0. 01秒ス テップ可変パルス動作との動作切替が可能であ る(図 1 ).

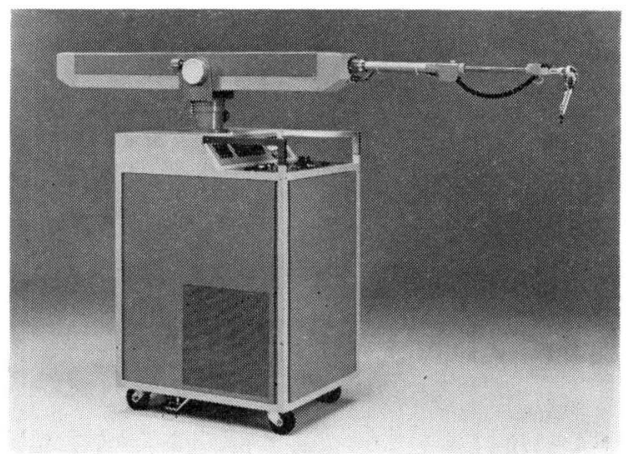

例, Vaporization（組織気化）を行ったもの11 例, Cutting と Vaporizationを併用したもの 1 例である.

麻酔: 舌白斑症例, 上咽頭癌局所再発例, 上 
顎癌局所再発例, 煩部粘膜癌局所再発例, 下咽 頭癌局所再発例（症例 $4,5,12,13,14$ ) では 局所麻酔下に行っているが，その他の症例では 全身麻酔下に行った。

出血量: 手術操作のうちの一部として合わせ てレーザー手術を行ったもの（症例 $6,7 ， 8$,

9，10，11）では多量の出血がみられているが, これは主手術操作によるものであって，レーザ 一手術によるあのではなく, レーザー手術のみ を行った例 $(1,2,3,4,5,12,13,14)$ で の出血は極めて少量である.

疼痛 : 術後疼痛は殆んど訴えなかった。

治療及び経過：良性腫瘍例では, 舌のリンパ 管腫, 乳頭腫, 白斑例に対しては開口位で舌を 挺出させ, また, 喉頭乳頭腫では喉頭戴開術を 行って声門下腔を充分直視下においてレーザー 手術を行っている。いずれ屯, 疼痛は極めて少 なく，すみやかな創面治痊経過を示し良好な䋂 過であった。図 2 に舌乳頭腫例（症例 2 ）の術 前, 術直後, 術後 5 日目, 退院時の所見を示し 図 3 亿喉頭乳頭腫例（症例 4 ）の術前, 術直後 の状態を示す。出血量が少なく, 速やかな治癒 過程を示している。

墨性腫瘍例については，上顎癌再発例（証例

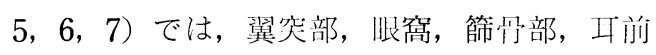

以上綠介して来た陨休経験から考えられる䦌 題点について若干の考按を加えたい.

1. Cutting か, Vaporization か.......荻峻 ガスレーザーは，その波長が $10.6 \mu$ であり，組 織の出調に影響されることなく切開, 凝周を行 うことが出来るという特徽を持っているので, 必ずしも一定した伦調を有しない腫瘍組織のレ ーザー手術には, 他の種類のレーザーよりも有 力である。現在までわれわれは，银性腫瘍では 切除摘出または気化消去を目的として Cutting または，Vaporization を併用して来ており， 㥲性腫瘍例では, 腫瘍組織を健康組織から切除 摘出するためよりもむしろ,レーザーの持つ腫
部に生じた局所再発腫瘍を Vaporization する ことによってよくコントロールすることが出来 ている. 図 4 に左耳前部に生じた再発腫瑒例 （症例 5 ）の術前と治癒後の状態を示す. 図 5 に篩骨部に生じた再発腫瘍とその治癒後の状態 を示す。上咽頭癌例では新鮮例（症例11）にお いては, 軟口蓋正中切離を行って上咽頭を直视 下におき, また, 局所再発例（症例12）では軟 山盖, 咽頭側索部の再発腫瘍へ直接 Vaporization を行ない, 再発をみていない。図 6 亿症 例12の術前, 退院時所見を示す. 口蓋癌例と翼 突部軟骨肉腫例の 2 例は腫瘍の消失を来すこと なく再発死亡した。

舌根部覀性黒色腫例（症例 9 ）では, 咽韻側 切開によって下咽頭を露出し, 腫瘍をその有茎 基部にて切除後,ただちに, 周囲 $2 \mathrm{~cm}$ 範囲内を レーザー烧灼した。 図 7 に症例 9 の咽頭側切開 孔からみた術前の腫愓とその術後の所見を示 す.少ない出血で完全に気化消去させるととが 出来ている.

しかし，局麻下で行った，舌白斑症(症例 4) 之上咽頭癌再発例 (症例 12), 上顎癌局所再発 例（症例 5 ）では焼灼时に発生する多量の帮が 患者の吸気小に混入し, 強い烗と息苦しさを泝 えた。

\section{按}

瘍緗胞の転移防止と気化消去の特徽を出かし て, Vaporization を行って米ている. 顔而i, 而，口腔などの良性腫瘍では，その基部を碓認 後健冰部から Cutting 在行って, 完全に摘出 されるが, 下咽頭, 声門, 声門下腔などの深部 のものでは focused beam による手術操俳は, ミスショットや over cutting による副損㑺の 伦険があるので, Vaporizationのうが安全の ように思わ机る。また，白斑怔や角化症など表 皮彺にのみ病変があるものでは Vaporization の才が適切であり，一j，基部が明確とならな いリンパ管腫や血管腫などでも, Vaporization のうが確実に消去しうるようである。琹性腫瘍 
例では，Vaporization による腫煌の気化消去 を目的として行っているが, 耳前部や頭蓋底の 一部，眼窩内など，再発腫瘍の底部が骨によっ て境されていて，深部への浸潤が防護されてい る部での気化消去は完全に行うことが出来る. また，硬膜に達した腫焬でも小さいものであれ ば Vaporization を適切に行うことによって出 侐む少なく，硬膜の外膜までを気化することが 出来て, 再発腫劰をコントロールすることが出 来る.しかし, 翼突部, 上頸部, 下頸部など, その深部に大血管があり, しかも, 癌浸潤深度 が確実につかめないものでは，レーザーは腫煬 の上層から気化燒灼していくのであるから，そ の効果の到達度を確認しながら, 一方では癌組 織の残存の有無を明視しながら, 血管損傷に注: 意しつつ行うことが大切で, 熟練を要する問題 であり，しかも，腫瘍消失までにかなりの長時 間を要するという久点がある。

2. 出力の問題‥レーザーのエネルギーは出 力と時間との積で表わされるといわれるが，実 際の臨木においては，単位部位を単位時間に橴 灼するには, 焦点直径 (focus) の程度と出力 とにかかっている。滝沢2)によれば，頭皮では 焦点直径 $0.5 \mathrm{~mm}$ で $60 \mathrm{~W}$ 以上, 硬膜切開には focused beam で 20W〜30W，筋組織は30W〜50 W, 皮膚の血管腫では defocused beam（值径 数mm) で $50 \mathrm{~W}$ が適量であるという。われわれの 経験では，10W，20W，30W，40Wについて試 みてみたが, 満足しうる焼灼力と切開速度を示 さなかった．頭頸部領域腫瘍に対して応用する 場合，良性腫瘍，悪性腫瘍を問わず， $50 \mathrm{~W} \sim 60$ W の focused beam による Cutting と defocused beam による Vaporization とが適し ていると考えている. 血管腫, 乳頭腫, 白班症: などでは, 焦点 $1 \mathrm{~mm} \sim 2 \mathrm{~mm}$ defocused beam, 50W〜60Wによって Vaporization が満 足されうるが，乙の同一条件を悪性腫瘍に応用 することは不適であって，焦点をしぼって 1.0 $\mathrm{mm} \sim 0.5 \mathrm{~mm}$ 程度にしないと充分に腫禓細胞気化 の目的を達しない。しかし，硬膜へ達している
再発腫瘍では, 焦点 $2 \mathrm{~mm}$ 程度の defocused beam によって低いエネルギーで少しづつ気化さ せた方が安全であると思われた。

3. 局所麻酔か, 全身麻酔か…頭頸部領域で は，他の領域と異って術野が気道または気道に 接近した部位であることも特徵である。レーザ 一外科は出血が少ないという特色があるが，著 しく多量の煙を生じるという久点あある．実際 にこの多量の煙は気道に対しては刺㦸性が強 く，気道刺㦸によって強い咳発作を誘発する. 出来るだけ吸引によって排煙を行うが，術野が 口腔，咽頭，喉頭などでは患者の吸気中に多量 の煙が混入し，強い息苦しさを訴えるために， 全身麻酔下に行う方が安全で確実のように考え られる。しかし, 耳前部, 眼窩, 顔面, 前額部, 頸部などでは，気道への気流をブロックしてお けば局所麻酔下に行うことも出来る。一方, 術 野以外の健康部の焼灼を防ぐためには，生食ガ 一ゼでカバーしておくことが大切であり，ま た，全身麻酔下に行う場合には，術野と插管于 ューブとが接近している部位，例えば，ロ内， 咽頭，喉頭などでは，レーザーによるチューブ 䛊損傷を防ぐために生食ガーゼで防護したり， アルミフォイルを卷いたりしているが，レーザ 一手術用の麻酔チューブの開発が望まれるとて ろである。

4. 本装置について…各種の頭頸部腫瘍の治 療のためには，前述のごとく，50W～60Wの出 力が適切であった。本装置は $0 \mathrm{~W} \sim 60 \mathrm{~W}$ の連続 可変出力となっているので, 頭頸部領域の良性 腫瘍のみならず，悪性腫瘍の治療にも適した装 置である。一方, 口内, 咽頭, 鼻腔, 顎下部な どは，術野が平面的でなく，立体的，空間的に 特殊な形態の部位であり，てのような部位のレ 一ザー手術では，その光線が直進性であるだけ に，マニピレーターのたくみな行動性が望まれ る. 本装置のマニピレーターは, 関節が少なく 光軸ずれがないという長所を有しているが, 微 妙な行動性に乏しいという短所があり，頭頸部 領域での応用には未だ改良されるべき点が残っ 
ている，また， 口腔，鼻腔などの診療では，膝 状の摂子が使われている。乙れは術者の器具を 持つ手が, 視野を防げないようにするための構
造である，頭頸部腫瘍レーザー手術では，膝状 マニピレーターが必要であると考えて試作を急 いでいる。

\section{ま と め}

1. 筑波大学耳鼻咽喉科で昭和54年11月 1 日から昭和 55 年 8 月 15 日までの間に行った 20 件 14 例の 頭頸部領域腫揚に対するレーザー手術の成績とその経験から考えられる問題点について報告した。

2. 良性腫瘍例は最適応例である. 悪性腫瘍では, 局所再発腫瘍のコントロールに有力であり, 悪性黑色腫症例は他に有力治療法がないだけに有望な適応例である. 悪性腫瘍でも表在性の小癌腫 では新鮮例の第 1 治療法となりうるであろう.

3. 悪性腫瘍再発例であっても表在性, 限局性なむのは基底が骨によって境されているもの（顔 面, 頭部, 眼窩, 翼突部の一部など）では, 完全に気化消去することが出来るが, 頸部, 翼突部な ごで大血管があり，しかも腫瘍浸潤の深度が明確でないものは不適である.

4. 頭頸部領域腫瘍に対するレーザー条件は良性, 悪性を問わず50W～60Wの出力が必要であり 血管腫, 乳頭腫, 白斑症などでは焦点 $1 \mathrm{~mm} \sim 2 \mathrm{~mm}$ defocused beam の Vaporization, 悪性腫瘍 では焦点 $1.0 \mathrm{~mm} \sim 0.5 \mathrm{~mm} の$ beam の Vaporization か Cutting, 硬膜へ達している再発腫焬に対し ては焦点 $2 \mathrm{~mm}$ 程度の defocused beam によって少しづつ外膜までを Vaporization すると安全で ある。

5. 麻酔はレーザーによって生じる多量の煙が気道へ入ることを防止出来る部位（顔面, 頭部, 眼窩, 頸部など）で, 表在性, 小腫煌であれば局所麻酔下に行うことが出来るが, 全身麻酔下の方 がより安全であり，その他の部位や深在性の浸潤腫瘍では気化消去させる場合でも安全確実であ る。しかし多量の煙は, 術者にとっても視野を阻害し気道を刺㦸するので排煙法の開発が考えられ なければならない。

6. 頭頸部領域は術野がせまく, 林酔チューブが通る部位である. 健康組織の誤焼灼防止には生 食ガーゼで術野以外を被う必要があり, 麻酔チューブの損傷防止には生食ガーゼ, アルミフォイル による防護を行っているが, レーザー外科用の森酔チューブの開発が望まれる。

7. マニピレーターに関しては, 頭頸部領域の解剖学的特殊性を考慮した機能, 形態の屯のの改 良, 試作が必要である。

文

1) C.K. N. Patel : High power carbon dioxide lasers, Scient. Am. 219:23 33, 1968.

2) 滝沢利明: 脳外科用炭酸ガスレーザーメス実用機 開発の研究. $\mathrm{Co}_{2}$ レーザーメス, 臨床ガイド, 頁 $5 \sim 46,1976$ 年, メジカルビュ一社.

3 ) 三橋重信, 他 : レーザー手術, 耳鼻 $25: 364$ 377, 1979.

4）村上嘉彦, 他：レーザー手術.耳鼻 $25 ： 358 〜$ $363,1979$.

5) H. Lenz et. al : Biophysikalische Grundlagen der Laserchirurgie und ihre bisherige Anwendung im HNO-Bereich. Laryng. Rhinol. 55 :

\section{献}

529 544, 1976.

6 ) M. B. Bassat et al. : The $\mathrm{Co}_{2}$ laser in surgery of the tongue. British J. of Plastic Surgery 31: 155 156, 1978.

7) M. B. Bassat et al. : Treatment of hereditary haemerrhagic telangiectasia of the nasal mucosa with the carbon dioxide laser, British J. of Plastic Surgery 31: 157 158, 1978.

8 ) K. Burian et al. : Zur mikrochirurgischen Therapie von Stimmband Karzinomen mit dem $\mathrm{C}_{\mathrm{O}_{2}}$-Laser. Laryng. Rhinol. $58: 551 \sim 556$, 1979. 


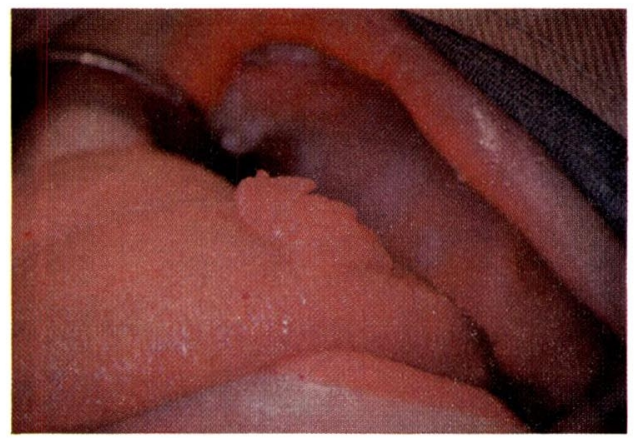

A

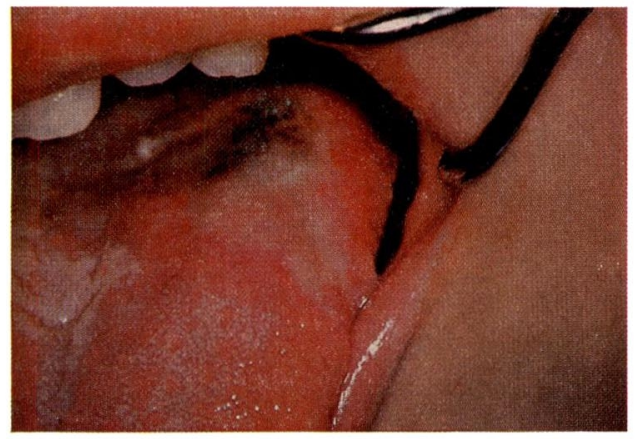

C

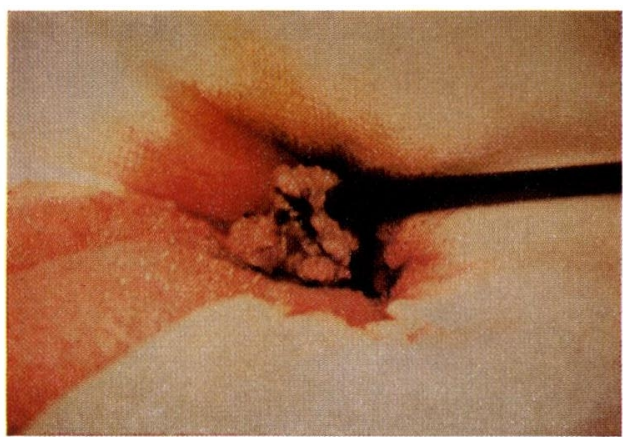

B

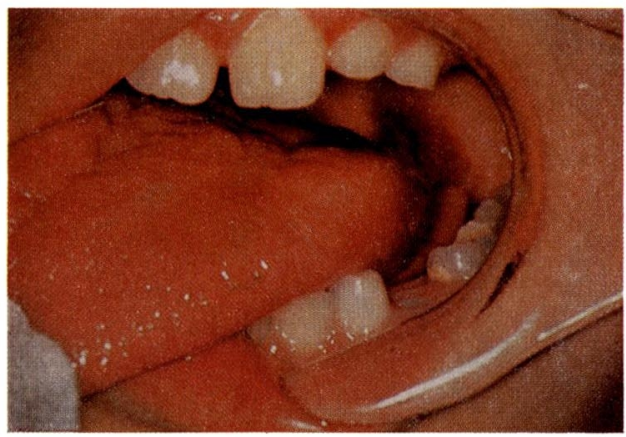

D

図 2. 症例 2.9 才, 男, 舌乳頭腫. $\mathrm{A}$; 術前. B ; 術中, Cutting によって切除を行っている. 出血 殆んどなし. C ; 術後 5 日目の状態, 術創周辺から上皮化が進んでいる. D ; 退院時治癒所見.

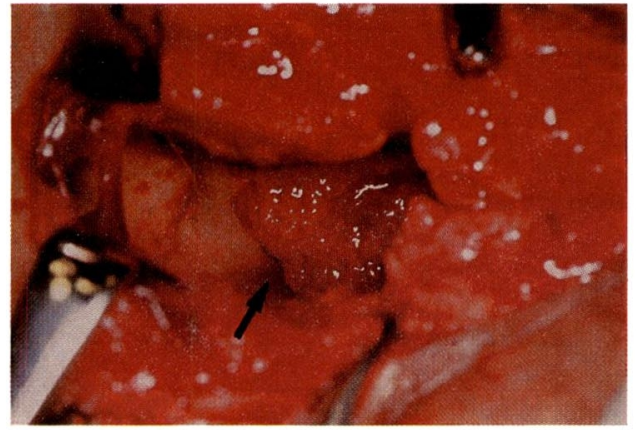

A

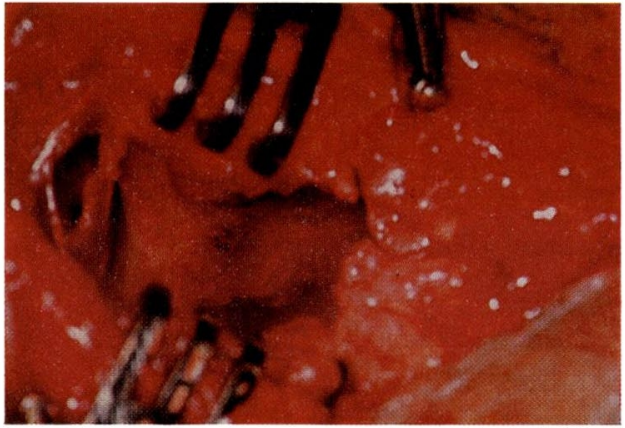

B

図 3. 症例 4.40才, 男, 喉頭乳頭腫. 喉頭截開術にて声門下に腫瘤を出す. A ; 術前所見（矢印）. $\mathrm{B}$; 術後所見. 




A

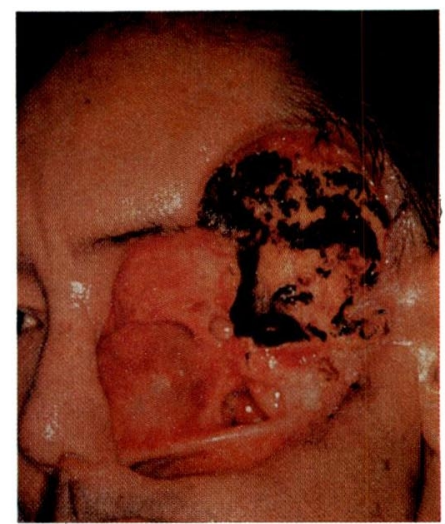

B

図 4. 症例 5.62 才, 男, 上顎癌術後側頭部再発. A ; 黒線は Cuttting による皮切部で, 辺縁の腫痹は Vaporization した. B ; 術後所見.

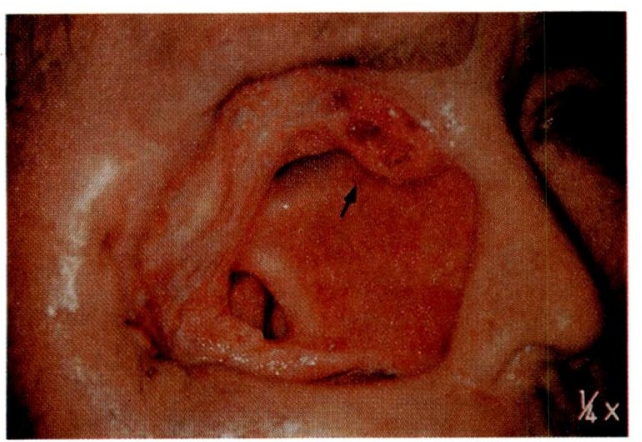

A

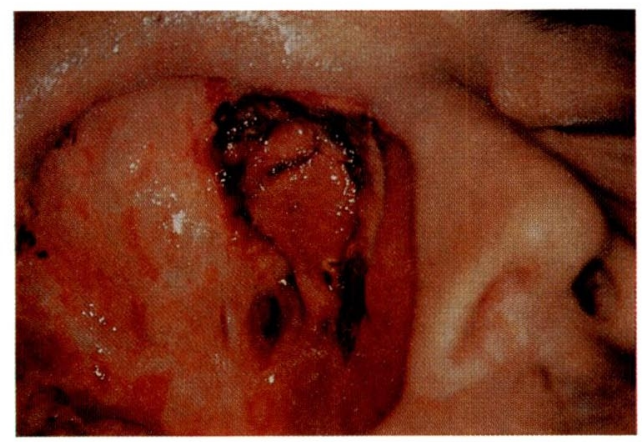

B

図 5. 症例 7.61 才, 男, 上顎癌術後穊骨部再発. A ; 術前所見 (矢印), B ; 術後所見.

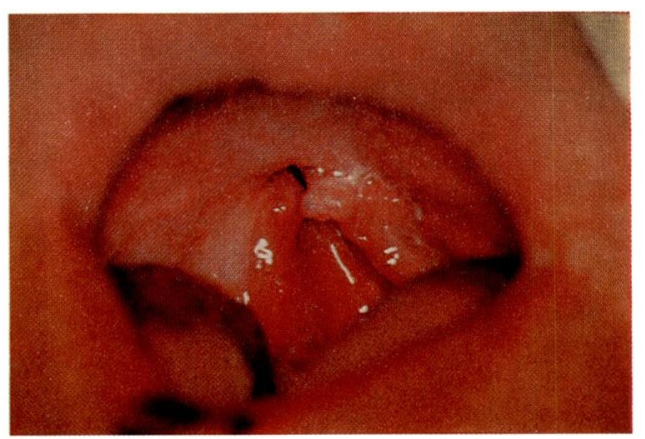

A

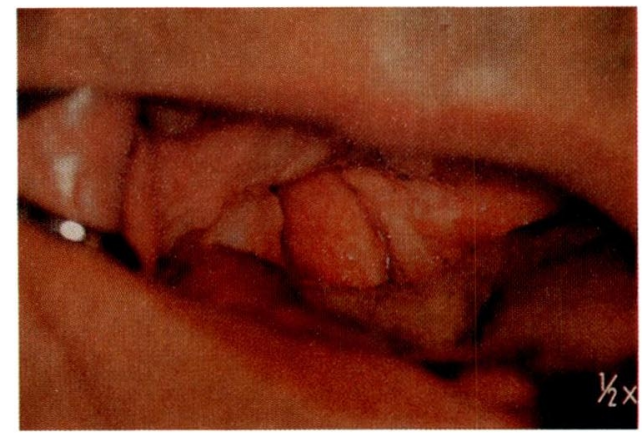

B

図 6. 症例12.78才, 男, 右上咽頭癌動注放射線併用療法後に左軟口蓋への局所再発. A ; 術前所見, $\mathrm{B} ;$; 術後退院時. 


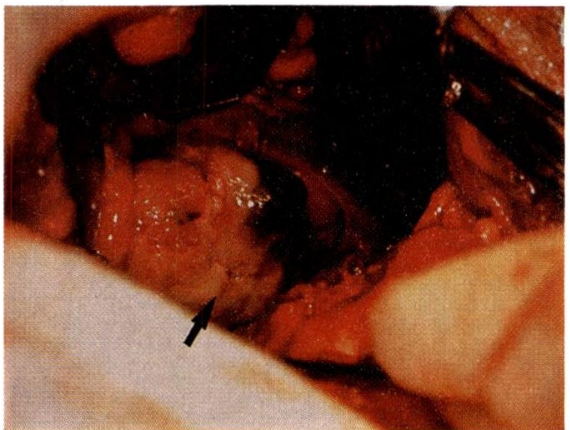

A

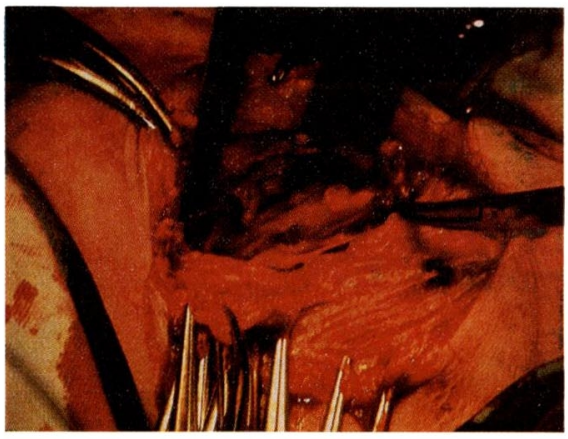

B

図 7 . 症例 9.59 才, 女, 舌根部悪性黒色腫. A ; 右咽頭側切開にて下咽頭を出し, 腫瘤（矢印）をみる. 術前所見. B ; Cutting によって腫瘤摘出後, その周辺を Vaporizationした. 術後所見. 出血が 極めて少い。

$$
\begin{aligned}
& \text { 原稿到着: 昭和 } 55 \text { 年 } 9 \text { 月 } 19 \text { 日 } \\
& \text { 別刷請求先 : 江口央美 } \\
& \text { 寀305 茨城県新治郡桜村 } \\
& \text { 筑波大学耳鼻咽㘈科 }
\end{aligned}
$$

